\title{
Consumption of pure oats by individuals with celiac disease: A position statement by the Canadian Celiac Association
}

\author{
Mohsin Rashid FRCPC ${ }^{1,2}$, Decker Butzner FRCPC ${ }^{1,3}$, Vernon Burrows $\mathrm{PhD}^{1,4}$, Marion Zarkadas MSc${ }^{1}$, \\ Shelley Case BSC ${ }^{1,5}$, Mavis Molloy BSc ${ }^{1,6}$, Ralph Warren FRCPC ${ }^{1,7}$, Olga Pulido MD ${ }^{8}$, Connie Switzer FRCPC 1,9
}

\begin{abstract}
M Rashid, D Butzner, V Burrows, et al. Consumption of pure oats by individuals with celiac disease: A position statement by the Canadian Celiac Association. Can J Gastroenterol 2007;21(10):649-651.
\end{abstract}

\begin{abstract}
The treatment of celiac disease is a strict adherence to a gluten-free diet for life. In the past, oats were considered to be toxic to individuals with celiac disease and were not allowed in a gluten-free diet. However, recent evidence suggests that oats that are pure and uncontaminated with other gluten-containing grains, if taken in limited quantities, are safe for most individuals with celiac disease. For adults, up to $70 \mathrm{~g}$ (1/2 to $3 / 4 \mathrm{cup})$ of oats per day and for children, up to $25 \mathrm{~g}$ ( $1 / 4$ cup) per day are safe to consume. These oats and oat products must fulfill the standards for a gluten-free diet set by the Canadian Food Inspection Agency and Health Canada. The Canadian Celiac Association, in consultation with Health Canada, Agriculture \& Agri-Food Canada and the Canadian Food Inspection Agency, has established requirements for growing, processing, and purity testing and labelling of pure oats. These strategies have led to the production of pure, uncontaminated oats for the first time in Canada. Oats and oat products that are safe for consumption by individuals with celiac disease and dermatitis herpetiformis are now commercially available in Canada.
\end{abstract}

Key Words: Celiac disease; Gluten-free diet; Oats; Position statement
La consommation d'avoine pure par des personnes atteintes de la maladie coliaque : Un document de principes de l'Association canadienne de la maladie cœliaque

Le traitement de la maladie coliaque consiste à respecter rigoureusement un régime sans gluten pendant toute la vie. Par le passé, l'avoine était considérée comme toxique pour les personnes atteintes de la maladie cœliaque et n'était pas autorisée dans un régime sans gluten. Cependant, d'après des données récentes, l'avoine pure non contaminée par d'autres céréales contenant du gluten, consommée en petite quantité, est sécuritaire pour la plupart des personnes atteintes de la maladie coliaque. Chez les adultes, il est sécuritaire de consommer jusqu'à $70 \mathrm{~g}$ ( $1 / 2$ à $3 / 4$ de tasse) d'avoine par jour, tandis que chez les enfants, cette quantité peut atteindre $25 \mathrm{~g}$ ( $1 / 4$ de tasse) par jour. L'avoine et les produits de l'avoine doivent respecter les normes d'un régime sans gluten établies par l'Agence canadienne d'inspection des aliments et Santé Canada. L'Association canadienne de la maladie cœliaque, en consultation avec Santé Canada, le ministère de l'Agriculture et de l'Agroalimentaire du Canada et l'Agence canadienne d'inspection des aliments, a établi des exigences pour cultiver, traiter et étiqueter l'avoine pure ainsi que pour en évaluer la pureté Pour la première fois au Canada, ces stratégies ont permis la production d'avoine pure et non contaminée. L'avoine et les produits de l'avoine qui peuvent être consommés en toute sécurité par les personnes atteintes de la maladie cœliaque et la dermatite herpétiforme sont désormais en vente au Canada.

Oats are a good source of vitamins and minerals, and contain approximately twice the protein content of rice. The starch in oats (composed of amylose and amylopectin) is easily digested. Oat oil ( $6 \%$ to $8 \%$ by weight) is largely polyunsaturated. Oats are rich in soluble dietary fibre, which may help reduce low-density lipoprotein cholesterol in hypercholesterolemic individuals. Oat groats also contain unique antioxidants (avenanthramides). The bran in oats can have a beneficial laxation effect. In the past, oats (avenin) were believed to be toxic to individuals with celiac disease and were not allowed in the gluten-free diet. However, recent evidence has shown that oats are safe for consumption by most individuals with celiac disease. Availability of oats will not only foods, especially gluten-free foods of good quality $(2,3)$.

${ }^{1}$ Professional Advisory Board, Canadian Celiac Association; ${ }^{2}$ Division of Gastroenterology and Nutrition, Department of Pediatrics, Dalhousie University, Halifax, Nova Scotia; ${ }^{3}$ Division of Gastroenterology, Department of Pediatrics, University of Calgary, Calgary, Alberta;

${ }^{4}$ Department of Agriculture and Agri-Food, Ottawa, Ontario; ${ }^{5}$ Consulting Dietitian, Regina, Saskatchewan; ${ }^{6}$ Kelowna General Hospital, Kelowna, British Columbia; ${ }^{7}$ Division of Gastroenterology, Department of Medicine, St Michael's Hospital, University of Toronto, Toronto;

${ }^{8}$ Bureau of Chemical Safety, Food Directorate, Health Products and Food Branch, Health Canada, Ottawa, Ontario; ${ }^{9}$ Division of Gastroenterology, Department of Medicine, University of Alberta, Edmonton, Alberta

Correspondence: Dr Mohsin Rashid, Division of Gastroenterology, Department of Pediatrics, Dalhousie University, IWK Health Centre,

5850 University Avenue, Halifax, Nova Scotia B3K 6R8. Telephone 902-470-8746, fax 902-470-7249,

e-mail mohsin.rashid@iwk.nshealth.ca

Received for publication December 11, 2006. Accepted January 18, 2007 
improve the nutritional value of a gluten-free diet but will also increase palatability, expand food choices and may improve the quality of life for those with celiac disease $(4,5)$.

Commercially available oats in North America are variably contaminated with gluten-containing grains $(6,7)$. Contamination can occur on the farm, during the growing cycle or during storage, cleaning, transportation or processing (8). There was a need to develop strategies that would provide oats that are pure and uncontaminated, making them safe for consumption by individuals with celiac disease and dermatitis herpetiformis.

The Professional Advisory Board of the Canadian Celiac Association, in collaboration with Health Canada, reviewed the literature on the safety of oats in celiac disease (9-27) and developed the following position statement on oats (28):

"The safety of oats in individuals with celiac disease has been extensively investigated. Clinical evidence confirms that consumption of pure, uncontaminated oats is safe in the amount of 50 to 70 grams per day (1/2$3 / 4$ cup dry rolled oats) by adults and 20 to 25 grams per day ( $1 / 4$ cup dry rolled oats) by children with celiac disease. Studies looking at the consumption of oats over five years have confirmed their safety. However, the studies looking at safety of oats in celiac disease have involved a small number of subjects, the oats used were pure, free of gluten contamination and the amount allowed per day was also limited.

In Canada, pure and uncontaminated* oats are now being produced. Individuals with celiac disease who wish to add oats or oat products to their diet must ensure that the oats they are eating are free from gluten contamination.

A small number of individuals with celiac disease may not tolerate even pure, uncontaminated oats. To ensure that persons with celiac disease are not intolerant to pure and uncontaminated oats, proper clinical follow up with the physician is advised when introducing oats to a gluten-free diet.

The Canadian Celiac Association will continue to monitor the scientific developments in the area of oats in celiac disease and will keep its members updated.

*These oats will meet or exceed the purity standards of Foundation \#1 as defined by the Canada Seeds Act" (29).

The following guidelines are recommended when starting oats in the diet of a patient with celiac disease:

1. The patient's celiac disease should be well controlled on a gluten-free diet and the patient should have no gastrointestinal complaints.

2. It is recommended that adults receive no more than $50 \mathrm{~g}$ to $70 \mathrm{~g}$ (1/2 to $3 / 4$ cup) of dry rolled oats daily and children receive no more than $20 \mathrm{~g}$ to $25 \mathrm{~g}$ (1/4 cup) of pure, uncontaminated oats daily.

3. The fibre content of an oat-containing diet is often higher than the typical gluten-free diet. When adding oats to the diet, individuals may experience a change in stool pattern or mild gastrointestinal symptoms, including abdominal bloating and flatulence. These symptoms should resolve within a few days.

4. There are case reports of individuals with celiac disease relapsing with the consumption of pure uncontaminated oats. Patients should be warned of this possibility. They should discontinue the oats and contact their physician if symptoms persist.

5. The physician or a dietitian should review the diet to ensure that the patient is not consuming foods that contain gluten.

6. Screening with an immunoglobulin A-tissue transglutaminase or immunoglubulin A-endomysial antibody may not identify the rare patient who reacts to oats. These tests are not sufficiently sensitive for detecting 'mild' dietary indiscretions, especially over a short period of challenge; ie, less than $100 \mathrm{mg}$ to $1000 \mathrm{mg}$ of gluten per day. A positive endomysial antibody or tissue transglutaminase will help confirm oats sensitivity but a negative one will not exclude oats sensitivity.

7. It is worthwhile to rechallenge patients if they wish to try oats again. Development of symptoms at the time of the second challenge would strongly suggest intolerance to oats. Extensive patient research suggests intolerance to oats occurs but is rare. The mechanism for this is unknown.

In consultation with Health Canada, Agriculture \& AgriFood Canada and the Canadian Food Inspection Agency (CFIA), requirements for growing, processing, and purity testing and labelling have been established. The Canadian Celiac Association has adopted the grade of Foundation \#1 (grown by Select Seed Growers) as the standard for seed to be used for patients with celiac disease, because this grade only permits 0 to 1 wheat, barley, rye or triticale seed $/ \mathrm{kg}$ of oat groats (approximately 30,000 to 40,000 oat groats $/ \mathrm{kg}$ ) to be present. The actual number of groats $/ \mathrm{kg}$ depends on the kernel weight of the seeds, which is a reflection of both genetic and environmental factors. Pedigreed Foundation seed is a very good measure of oat purity because CFIA inspectors carefully examine thousands of plants in the field (large sample size) and official seed testing laboratories monitor the purity of the harvested grain before deciding if it meets Foundation \#1 classification. Seeds produced in this dedicated system can be delivered to a dedicated Hazard Analysis Critical Control Points certified oat processing facility and made into product. The rolled oats or the oat flour made into products from these oats are then evaluated for gluten content using an R5-ELISA test $(30,31)$. This test will detect gluten contamination with as little as $3 \mathrm{ppm}$. One wheat seed per kilogram of oats will contribute approximately $1 \mathrm{ppm}$ to $2 \mathrm{ppm}$ of gluten $/ \mathrm{kg}$ in a thoroughly mixed (essential) oat flour. This degree of contamination will not be detected even with the R5-ELISA test and is well below the 20 ppm maximum allowed in gluten-free foods by the CFIA and Health Canada.

To produce pure, uncontaminated oats, the manufacturer must have a dedicated system, including fields, harvesting, production, storage, transportation, manufacturing equipment and a production plant. Growers and processors able to meet these requirements were contacted. The CFIA and Health Canada were consulted to establish their support and labelling requirements. The oat food manufacturers will ensure that the pure oats they use and sell are grown and processed in the prescribed dedicated manner and the oats and products pass 'track and trace procedures'. The pure oats that are sold as rolled oats, oat groats or whole oat flour, or the products that are made from these oats must have passed a CFIA field inspection (visual and 
chemical), a registered seed analysis to qualify for the Foundation \#1 rating and an R5-ELISA test in a Hazard Analysis Critical Control Points certified food processing facility. The Canadian Celiac Association is working on the development of a special trademark that would identify these pure and uncontaminated oats, thereby making it easier for the consumer to identify products that meet the strict guidelines.

In Canada, pure and uncontaminated oats are now commercially available. Since 2005, one company, based in the

\section{REFERENCES}

1. Shan L, Molberg $\varnothing$, Parrot I, et al. Structural basis for gluten intolerance in celiac sprue. Science 2002;297:2275-9.

2. Zarkadas M, Cranney A, Case S, et al. The impact of a gluten-free diet on adults with coeliac disease: Results of a national survey. J Hum Nutr Diet 2006;19:41-9.

3. Rashid M, Cranney A, Zarkadas M, et al. Celiac disease: Evaluation of the diagnosis and dietary compliance in Canadian children. Pediatrics 2005;116:e754-9.

4. Thompson T. Do oats belong in a gluten-free diet? J Am Diet Assoc 1997;97:1413-6.

5. Thompson T. Oats and the gluten-free diet. J Am Diet Assoc 2003;103:376-9.

6. Thompson T. Gluten contamination of commercial oat products in the United States. N Engl J Med 2004;351:2021-2.

7. Thompson T. Contaminated oats and other gluten-free foods in the United States. J Am Diet Assoc 2005;105:348.

8. Størsrud S, Malmheden Yman I, Lenner RA. Gluten contamination in oat products and products naturally free from gluten. Eur Food Res Technol 2003;217:481-5.

9. Arentz-Hansen H, Fleckenstein B, Molberg $\varnothing$, et al. The Molecular basis for oat intolerance in patients with celiac disease. PLoS Med 2004;1:e1.

10. Hardman C, Fry L, Tatham A, Thomas HJ. Absence of toxicity of avenin in patients with dermatitis herpetiformis. N Engl J Med 1999;340:321.

11. Högberg L, Laurin P, Fälth-Magnusson K, et al. Oats to children with newly diagnosed coeliac disease: A randomised double blind study. Gut 2004;53:649-54.

12. Hoffenberg EJ, Haas J, Drescher A, et al. A trial of oats in children with newly diagnosed celiac disease. J Pediatr 2000;137:361-6.

13. Hollén E, Högberg L, Stenhammar L, Fälth-Magnusson K, Magnusson KE. Antibodies to oat prolamines (avenins) in children with coeliac disease. Scand J Gastroenterol 2003;38:742-6.

14. Hollén E, Holmgren Peterson K, Sundqvist T, et al. Coeliac children on a gluten-free diet with or without oats display equal anti-avenin antibody titres. Scand J Gastroenterol 2006;41:42-7.

15. Janatuinen EK, Kemppainen TA, Julkunen RJ, et al. No harm from five year ingestion of oats in coeliac disease. Gut 2002;50:332-5.

16. Janatuinen EK, Kemppainen TA, Pikkarainen PH, et al. Lack of cellular and humoral immunological responses to oats in adults with coeliac disease. Gut 2000;46:327-31. province of Quebec, has produced and marketed oats that meet the required purity standards. These oats are now available to consumers as rolled oats, oat flour and whole oat kernels (groats). It is expected that other Canadian companies will also start producing pure oats in the coming year.

In conclusion, oats that are pure and uncontaminated by gluten-containing grains are safe for consumption by most individuals with celiac disease, when taken in limited quantities. The availability of oats would improve food choices for those on a gluten-free diet.

17. Janatuinen EK, Pikkarainen PH, Kemppainen TA, et al. A comparison of diets with and without oats in adults with celiac disease. N Engl J Med 1995;333:1033-7.

18. Kilmartin C, Lynch S, Abuzakouk M, Wieser H, Feighery C. Avenin fails to induce a Th1 response in coeliac tissue following in vitro culture. Gut 2003;52:47-52.

19. Peräaho M, Collin P, Kaukinen K, Kekkonen L, Miettinen S, Maki M. Oats can diversify a gluten-free diet in celiac disease and dermatitis herpetiformis. J Am Diet Assoc 2004;104:1148-50.

20. Peräaho M, Kaukinen K, Mustalahti K, et al. Effect of an oatscontaining gluten-free diet on symptoms and quality of life in coeliac disease. A randomized study. Scand J Gastroenterol 2004;39:27-31.

21. Picarelli A, Di Tola M, Sabbatella L, et al. Immunologic evidence of no harmful effect of oats in celiac disease. Am J Clin Nutr 2001;74:137-40.

22. Reunala T, Collin P, Holm K, et al. Tolerance to oats in dermatitis herpetiformis. Gut 1998;43:490-3.

23. Schmitz J. Lack of oats toxicity in coeliac disease. BMJ 1997;314:159-60.

24. Srinivasan U, Leonard N, Jones E, et al. Absence of oats toxicity in adult coeliac disease. BMJ 1996;313:1300-1.

25. Størsrud S, Hulthén LR, Lenner RA. Beneficial effects of oats in the gluten-free diet of adults with special reference to nutrient status, symptoms and subjective experiences. Br J Nutr 2003;90:101-7.

26. Storsrud S, Olsson M, Arvidsson Lenner R, Nilsson LA, Nilsson O, Kilander A. Adult coeliac patients do tolerate large amounts of oats. Eur J Clin Nutr 2003;57:163-9.

27. Lundin KE, Nilsen EM, Scott HG, et al. Oats induced villous atrophy in coeliac disease. Gut 2003;52:1649-52.

28. Professional Advisory Board of the Canadian Celiac Association: Position statement on oats. <http://www.celiac.ca/Articles/ PABoats.html> Version current at July 11, 2007.

29. Department of Justice Canada: Seeds Act (RS, 1985, c S-8) $<$ http://laws.justice.gc.ca/en/S-8/text.html> Version current at July 10, 2007.

30. Osman AA, Uhlig HH, Valdes I, Amin M, Méndez E, Mothes T. A monoclonal antibody that recognizes a potential coeliac-toxic repetitive pentapeptide epitope in gliadins. Eur J Gastroenterol Hepatol 2001;13:1189-93.

31. Valdes I, Garcia E, Llorente M, Mendez E. Innovative approach to low-level gluten determination in foods using a novel sandwich enzyme-linked immunosorbent assay protocol. Eur J Gastroenterol Hepatol 2003;15:465-74. (Erratum in 2003;15:839). 


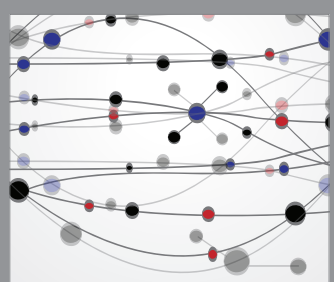

The Scientific World Journal
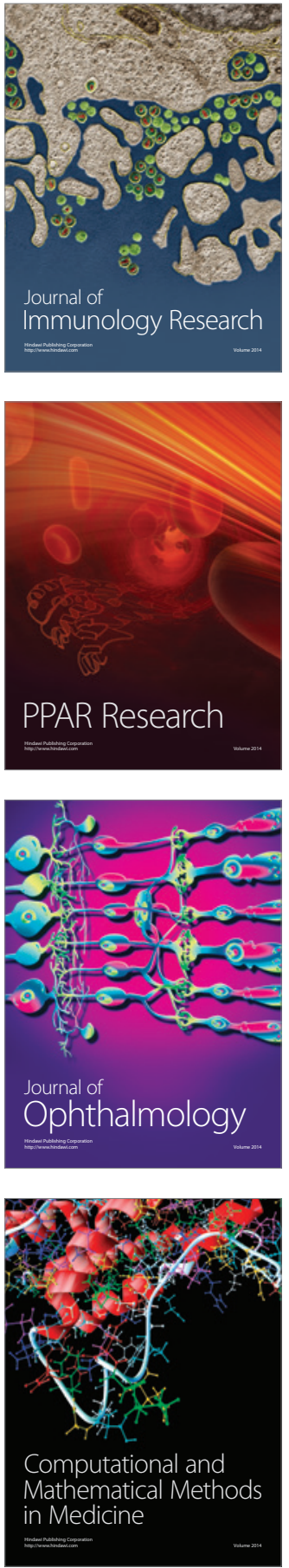

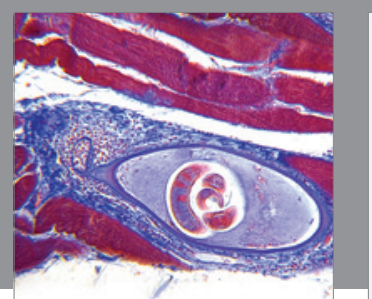

Gastroenterology Research and Practice

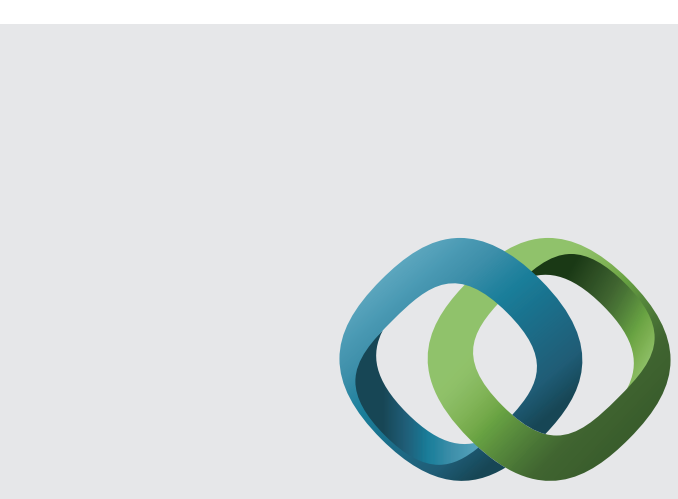

\section{Hindawi}

Submit your manuscripts at

http://www.hindawi.com
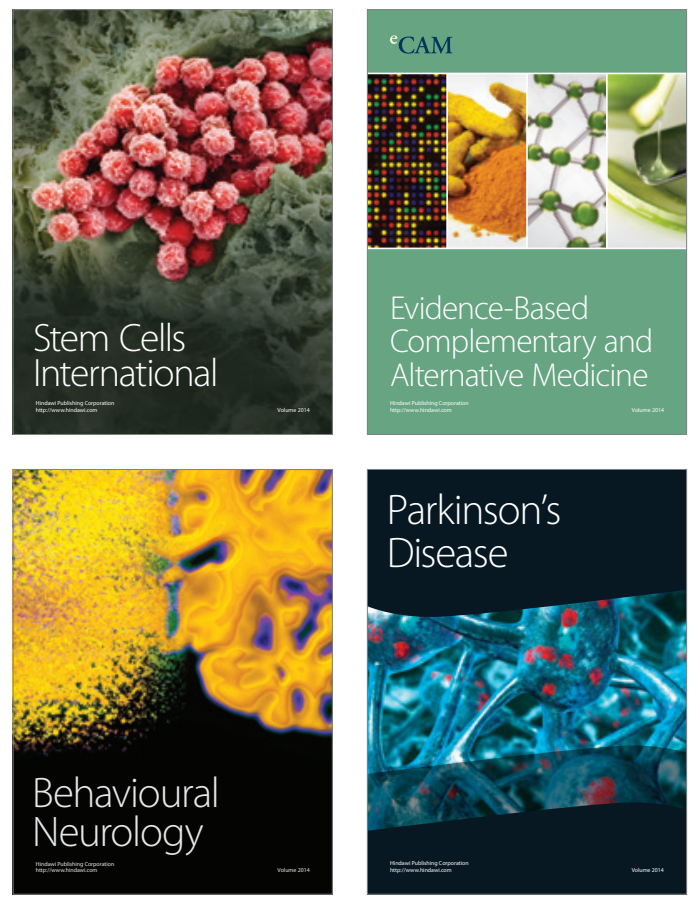
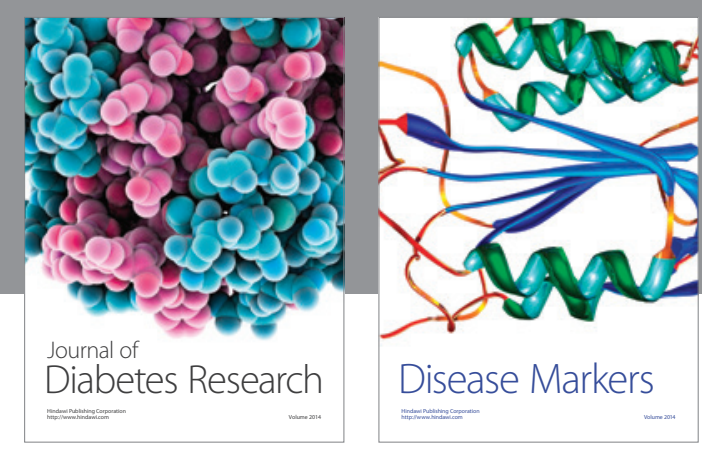

Disease Markers
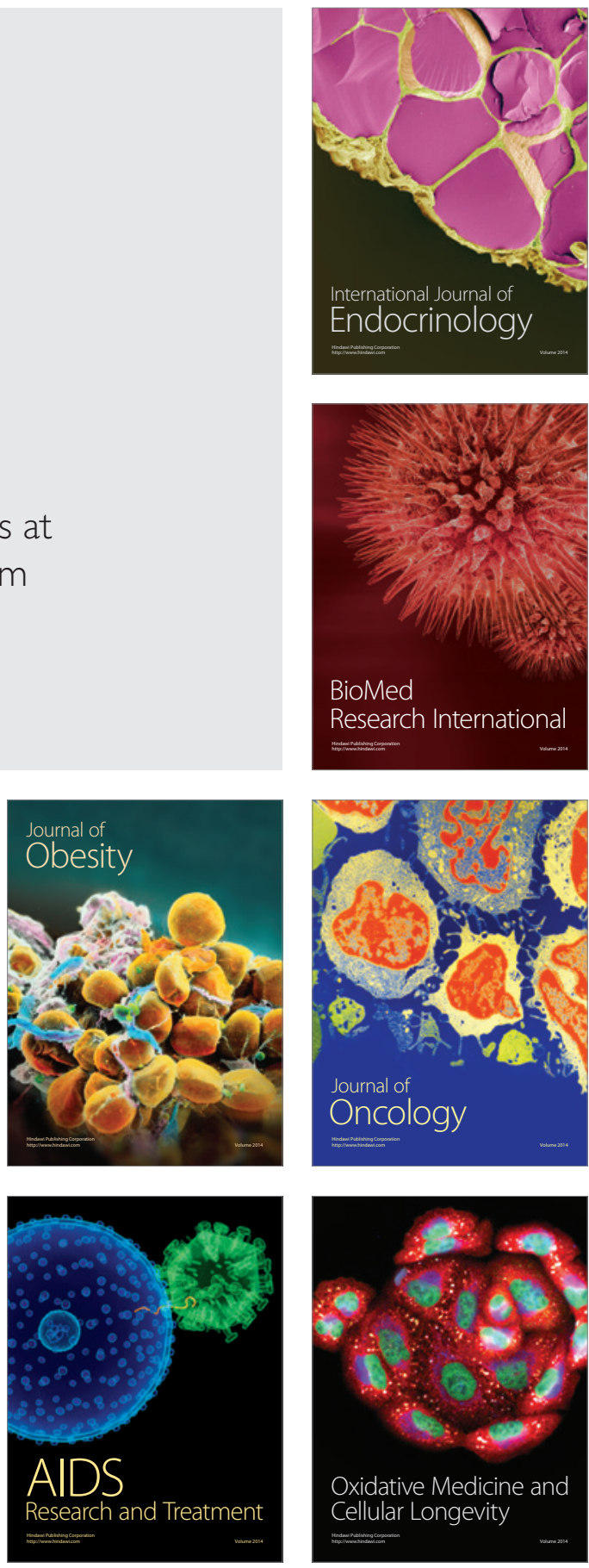